\title{
ARAB LANGUAGE LEARNING MANAGEMENT IN PESANTREN
}

Ade Nandang $S,{ }^{1}$ Hary Priatna Sanusi²

Fakultas Tarbiyah dan Keguruan UIN Sunan Gunung Djati Bandung adenandang@uinsgd.ac.id, harysanusi@yahoo.co.id

\begin{abstract}
Abstrak :
Penelitian ini dilatarbelakangi bahwa pembelajaran Bahasa Arab dengan segala problematikanya menuntut adanya variasi model dan pendekatan serta manajerial yang baik yang harus dilakukan oleh para pengajar maupun lembaga dalam hal ini pondok pesantren. Kesenjangan kompetensi awal antara masingmasing santri dalam satu rombongan belajar serta latar belakang pendidikan mereka yang beragam pula memberikan kontribusi permasalahan tersendiri bagi pengajar. Dengan mencoba mencari hubungan antara kompetensi dasar Bahasa Arab yang dimiliki santri dengan kondisi nyata lembaga, tulisan ini mencoba mencarikan titik temu antara proses pembelajaran Bahasa Arab dengan manajemen pembelajaran mulai dari perencanaan, pengorganisasian, pelaksanaan dan pengawasan. Pembelajaran keterampilan-keterampilan dasar bahasa yang meliputi mendengar (istima'), berbicara (kalam), membaca (qira'ah) dan menulis (kitabah) dilakukan dengan memperhatikan tingkat penguasaan awal santri. Tujuan penelitian ini adalah mendeskripsikan manajemen pembelajaran bahasa Arab dalam rangka meningkatkan kemampuan santri dalam berbahasa sebagai alat komunikasi dan proses pembelajaran. Metode penelitian yang digunakan dalam penelitian ini adalah metode deskriptif dengan pendekatan penelitian kualitatif. Teknik pengumpulan data yang digunakan melalui observasi, wawancara, dan dokumentasi. Hasil penelitian ini diharapkan dapat berguna bagi pengembangan berbahasa Arab di lingkungan Pondok Pesantren.
\end{abstract}

Kata Kunci : Manajemen, Pembelajaran, Bahasa Arab, Pondok Pesantren

\section{PENDAHULUAN}

Salah satu misi pendidikan di Indonesia adalah meningkatkan kualitas sumber daya manusia. Lulusan pendidikan yang berkualitas akan menjadi modal utama pembangunan nasional, terutama untuk perkembangan ekonomi (Shaleh, 2004: 123). Semakin banyak orang yang berpendidikan, semakin mampu bagi suatu negara untuk membangun bangsanya. Dengan Keterampilan, ilmu pengetahuan, agama, dan teknologi, pemerintah lebih mudah dalam menggerakkan pembangunan nasional. Investasi pendidikan juga akan memberikan nilai balik yang lebih tinggi dalam investasi fisik di bidang lain. Nilai balik pendidikan adalah perbandingan antara total biaya yang dikeluarkan untuk membiayai pendidikan dengan total pendapatan yang akan diperoleh setelah seseorang lulus dan memasuki dunia kerja. (Rayuni, 2010 : Vol XV, 01) 
Manajemen lembaga pendidikan mencakup pengembangan manajemen pembelajaran. Sesuangguhanya, sebesar apa pun masukan dalam lembaga pendidikan ditambah atau diperbaiki, lulusannya tetap tidak akan optimal, apabila faktor manajemen pembelajaran yang merupakan aspek yang sangat strategis dalam proses belajar mengajar tidak diberi perhatian. Manajemen pembelajaran adalah bagian pengelolaan terdepan yang mengembangkan kualitas setiap masukan pada aspek proses dan interaksi dalam sistem belajar mengajar. Di sini pendidik memiliki peran yang besar untuk mendorong atau menghambat upaya inovasi baik yang berasal dari luar maupun yang timbul dari dalam pembelajaran di lembaga pendidikannya. Pendidik harus mampu memutuskan apa yang harus diajarkan, bagaimana menyajikan bahan pelajaran, dan bagaimana menentukan cara pengajaran agar peserta didik mengerti apa yang diajarkan dan mampu menerapkan dalam kehidupan nyata, sehingga dalam hal ini kemampuan manajemen pembelajaran seorang pendidik sangat penting dan menentukan untuk mencapai keberhasilan belajar.

Berdasarkan uraian di atas, jelaslah bahwa manajemen pembelajaran merupakan faktor penting untuk menentukan keberhasilan proses pendidikan yang berlangsung di sekolah. Oleh karena itu, perhatian yang sungguhsungguh terhadap manajemen pembelajaran akan dapat mendorong peningkatan kualitas pendidikan. Ini tidak terbatas hanya pada lembaga pendidikan umum, tetapi juga pada lembaga pendidikan keagamaan, seperti pesantren.

Pembelajaran bahasa Arab secara historis telah ada sejak masa khulafa al-rasyidīn yaitu pada masa khalifah Umar bin Khatab yang dilaksanakan dengan sistem halaqah pada lembaga pendidikan yang dikenal dengan nama kuttab. Halaqah adalah suatu bentuk pembelajaran yang dilaksanakan dalam bentuk lingkaran, yang dipandu oleh seorang guru (syekh), yang duduk melantai bersama peserta didiknya dalam rangka mengajarkan dan menelaah ilmu pengetahuan baik ilmu agama maupun yang bersifat non-agamis. Pada masa ini, tuntutan untuk belajar bahasa Arab sudah mulai tampak, orang yang baru masuk Islam yang berasal dari daerah yang ditaklukkan harus belajar bahasa Arab jika ingin belajar dan memahami pengetahuan Islam 
Juwairiyah Dahlan mengemukakan bahwa pembelajaran bahasa Arab bertujuan di antaranya agar peserta didik dapat menguasai bahasa Arab sebagaimana penutur aslinya atau paling tidak mendekati keadaan, menumbuhkan kemampuan peserta didik agar dapat memahami bahasa Arab pada saat mendengarkannya, dapat mengucapkan bahasa Arab dengan benar dan tepat, dapat membaca tulisan-tulisan Arab disertai dengan pengertian yang jelas, serta dapat menulis bahasa Arab dengan cermat dan lancar. (Juwairiyah Dahlan, 1992 : 19) Selain itu bertujuan agar peserta didik dapat mengetahui karakteristik bahasa Arab dan dapat membedakannya dari bahasa-bahasa lain, baik pada aspek bunyi, kosa kata, struktur, dan sebagainya serta dapat mengenal kebudayaan bangsa Arab, karakternya, lingkungan mereka hidup, dan interaksi sosialnya.

Bahasa merupakan penghubung antara manusia dengan manusia, manusia dengan masyarakat dan masyarakat dengan masyarakat lainnya. Menurut Ibnu Jinni, Bahasa adalah suara yang digunakan oleh manusia dalam mengutarakan maksud dan tujuan mereka secara lisan. Dapat dikatakan bahwa bahasa arab adalah bahasa yang digunakan oleh orang-orang arab untuk mengutarakan maksud dan tujuan mereka secara lisan, bahasa arab juga berasal dari suku Quraisy di daerah arab dan kemudian menyebar diseluruh penjuru dunia bersama dengan meluasnya agama Islam dan Al- Qur 'an. Bahasa arab sendiri memiliki 4 maharoh yang harus dimiliki oleh sipembicara agar bisa sempurna, yaitu: Maharotul Istima' (keterampilan mendengar), Maharotul Kalam (keterampilan berbicara), Maharotul Qiro'ah (Keterampilan membaca) dan Maharotul Kitabah (keterampilan menulis).

\section{METODOLOGI}

Dalam penelitian ini peneliti menggunakan metode penelitian kualitatif dengan menggunakan pendekatan bersifat analisis deskriptif. Pendekatan yang bersifat analisis deskriptif adalah sebuah bentuk pengumpulan data secara kaya dari suatu fenomena yang ada untuk dianalisis, sehingga diperoleh gambaran terhadap apa yang sudah diteliti. data yang dikumpulkan berupa kata- kata, gambar, dokumen, serta tingkah laku. Selain itu peneliti bermaksud memahami 
situasi sosial secara mendalam, menemukan pola, hipotesis dan teori. Selain alasan tersebut, peneliti juga mempunyai beberapa pertimbangan-pertimbangan.

Pertama, menyesuaikan metode kualitatif lebih mudah apabila berhadapan dengan kenyataan jamak. Kedua, metode ini menyajikan secara langsung hakikat hubungan antara peneliti dan responden. Ketiga, metode ini lebih peka dan dapat menyesuaikan diri dengan banyak penajaman pengaruh bersama terhadap pola-pola nilai yang dihadapi (Moleong 2007:10).

Dalam penelitian ini yang menjadi instrumen penelitian adalah pengelola dan para pendidik bahasa Arab yang masih aktif pada pondok pesantren Pesantren Riyadhul Ulum Wa Da'wah dan Pesantren Darussalam Kab. Tasikmalaya.

Adapun teknik-teknik yang digunakan adalah sebagai berikut : (1) Metode Observasi. Metode observasi dilakukan dengan cara melakukan pengamatan secara langsung terhadap fenomena yang akan diteliti. Dimana dilakukan pengamatan atau pemusatan perhatian terhadap obyek dengan menggunakan seluruh alat indera. Jadi mengobservasi dapat dilakukan melalui penglihatan, penciuman, pendengaran dan pengecap (Arikunto, 1997:204). (2) Metode Wawancara. Wawancara adalah percakapan dengan maksud tertentu. Teknik Wawancara yang digunakan dalam penelitian ini adalah wawancara terstruktur dengan menggunakan alat bantu yaitu pedoman wawancara, (3) Metode Dokumentasi. Dokumentasi yaitu teknik yang digunakan untuk mencari data mengenai hal-hal atau variabel yang berupa catatan, transkrip, buku, surat kabar, majalah, prasasti, notulen rapat, agenda, dan sebagainya (Arikunto, 2001:206). Metode ini digunakan untuk memperoleh data mengenai perangkat pembelajaran para pendidik, daftar nama-nama santri.

\section{PEMBAHASAN}

\section{Manajemen Pembelajaran}

Proses belajar mengajar di satuan pendidikan dipengaruhi oleh manajemen pembelajaran yang dilakukan pimpinan lembaga pendidikan dan para pendidiknya. Manajemen pembelajaran memiliki peranan penting di setiap 
satuan pendidikan karena dapat menentukan kualitas lulusan. Manajemen pembelajaran berarti kemampuan pendidik dalam mendayagunakan sumber daya yang ada, melalui kegiatan menciptakan dan mengembangkan kerja sama, sehingga terciptanya pembelajaran untuk mencapai tujuan pendidikan di kelas secara efektif dan efisien. (Yanti Sri Danarwati, Jurnal Pendidikan).

Kemampuan mengatur proses belajar mengajar yang baik dapat membetuk kondisi yang memungkinkan peserta didik untuk belajar, sehingga merupakan titik pangkal keberhasilan dalam pengajaran. Peserta didik dapat belajar dalam suasana wajar, tanpa tekanan dan dalam kondisi yang merangsang untuk belajar. Dalam kegiatan belajar mengajar peserta didik memerlukan sesuatu yang memungkinkan mereka berkomunikasi secara baik, meliputi komunikasi guru dengan peserta didik, peserta didik dengan lingkungan, peserta didik dengan bahan ajar dan peserta didik dengan dirinya sendiri. (St. Fatimah Kadir, 2014 : Jurnal Al-Ta'dib, Vol. 7 No. 2.

Proses belajar mengajar yang dimaksud adalah aktivitas nyata yang dirancang secara khusus dalam kegiatan pembelajaran yang melibatkan guru dengan peserta didik guna mencapai tujuan pendidikan. Tujuan pendidikan yang dimaksud adalah tujuan pendidikan yang telah ditetapkan sebelumnya, baik tujuan pendidikan nasional, tujuan instutisional dan tujuan instruksional. Dengan kata lain proses belajar mengajar adalah "aktivitas yang disepakati dan dilakukan guru-murid untuk mencapai tujuan pendidikan secara optimal”

\section{a. Perencanaan Pembelajaran}

Perencanaan pembelajaran merupakan hal penting untuk memulai kegiatan pembelajaran dan mempengaruhi proses keberhasilan pendidikan. Perencanaan pembelajaran berkaitan dengan kemampuan untuk membuat keputusan tentang pengorganisasian, implementasi, dan evaluasi pembelajaran. Perencanaan pembelajaran adalah tugas penting guru untuk mempertimbangkan tentang siapa mengerjakan apa, kapan dilaksanakan dan bagaimana melaksanakannya, perintah pembelajaran yang terjadi, di mana kejadian terjadi, perkiraan waktu yang digunakan untuk pembelajaran, dan sumber-sumber serta bahan yang dibutuhkan.

Abdul Majid menjelaskan makna perencanaan pembelajaran adalah 
proses penyusunan materi pelajaran, penggunaan media pengajaran, penggunaan pendekatan dan metode pengajaran, dan penilaian dalam suatu alokasi waktu yang akan dilaksanakan pada masa tertentu untuk mencapai tujuan yang telah ditentukan. (Abdul Majid, 2009 : 17)

Komponen perencanaan pembelajaran adalah aspek penting yang harus diperhatikan karena berkaitan dengan aktivitas pembelajaran itu sendiri, yang berhubungan dengan kebutuhan pendidik dalam mendidik peserta didik. Menurut Alben Ambarita komponen pembelajaran ini merupakan hal yang utama dalam interaksi guru dan peserta didik untuk menyampaikan konsep atau keterampilan agar dikuasai peserta didik. (Alben Ambarita, 2006 : 75) Pimpinan lembaga diharapkan mampu mengkoordinasikan pendidik dalam perencanaan dan pelaksanaan pembelajaran:

1) Penyusunan silabus, program tahunan, program semester, dan mid semester.

2) Penyusunan desain pembelajaran peserta didik.

3) Penguasaan dan implementasi metode pembelajaran.

4) Penilaian sebagai uji kompetensi.

5) Kontrol dalam pencapaian indikator keberhasilan peserta didik.

Argumentasi lain dijelaskan Kenneth D. Moore mengenai komponen perencanaan pembelajaran meliputi:

1) Topik bahasan.

2) Tujuan pembelajaran (kompetensi dan indikator kompetensi).

3) Materi pelajaran.

4) Kegiatan pembelajaran.

5) Alat atau media yang dibutuhkan.

6) Evaluasi hasil belajar. (Alben Ambarita, $2006: 75$ )

Perencanaan pembelajaran mempengaruhi kualitas lulusan satuan pendidikan, oleh sebab itu, pemerintah membuat peraturan pemerintah tentang standar nasional pendidikan untuk mengatur pengelolaan pendidikan. Menurut PP No.19/2005 tentang Standar Nasional Pendidikan pada Pasal 20 disebutkan, "perencanaan proses pembelajaran meliputi silabus dan rencana pelaksanaan pembelajaran yang memuat sekurang-kurangnya tujuan 
pembelajaran, materi ajar, metode pengajaran, sumber belajar, dan penilaian hasil belajar".

Pondok Pesantren Riyadhul Ulum Wada'wah dan Darusslam Tasikmalaya salah satu jenis pendidikan keagamaan yang diselenggarakan menggunakan jalur pendidikan nonformal. Fungsi dari jalur pendidikan nonformal menurut UU No. 20/ 2003 tentang Sistem Pendidikan Nasional pada Pasal 26 disebutkan "pendidikan nonformal diselenggarakan bagi warga masyarakat yang memerlukan layanan pendidikan yang berfungsi sebagai pengganti, penambah, dan atau pelengkap pendidikan formal dalam rangka mendukung pendidikan sepanjang hayat".

Mengenai prinsip penyelenggaraan pendidikan nonformal, dalam Peraturan Pemerintah No. 17/ 2010 tentang Pengelolaan dan Penyelenggaraan Pendidikan pada Pasal 102 ayat 3 ditegaskan "pendidikan nonformal diselenggarakan berdasarkan prinsip dari, oleh, dan untuk masyarakat". Artinya mengacu amanat konstitusi di atas, proses perencanaan dan pengembangan pembelajarannya dapat dibuat sesuai dengan potensi dan kemampuan pesantren setempat tanpa ada panduan yang baku, sehingga dapat dikatakan Pondok Riyadhul Ulum Wada'wah dan Darussalam Tasikmalaya dapat merencanakan, melaksanakan, dan mengevaluasi pembelajaran sendiri.

Perencanaan pembelajaran yang dilakukan oleh Ustadz pengampu mata pelajaran Bahasa Arab di Pesantren Riyadhul Ulum Wa Da'wah dan Pesantren Darussalam Kab. Tasikmalya terlebih dahulu membuat perencanaan pelaksanaan pembelajaran dalam bentuk l'dadu At Tadris sebelum mengajarkan materi ajar pada para santri, yang akan menjadi tolok ukur bagi udtadz dalam mengajar. Ustdaz juga memilih dan mempersiapkan materi ajar yang akan diajarkan pada peserta didik berdasarkan kurikulum yang sudah dipersiapkan salah satu cotoh dasar dari buku pembelajarannya adalah Tamrin Al Lughah, Balagah, mustolah sebagai sumber belajar.

Silabus dan Rancangan Pelaksanaan Pembelajaran (I'dadu At Atadris) secara tertulis menunjukkan para ustad di Riyadhul Ulum Wa Da'wah dan Pesantren Darussalam Kab. Tasikmalya belumlah faham mengenai tata cara 
membuat RPP dan tahapan-tahapan yang harus dilengkapi sebelum melaksanakan proses belajar mengajar. Mencermati format kurikulum dan target atau kompetensi yang akan diraih menunjukkan secara prinsip silabus dan RPP ada, tetapi tidak ada secara de facto atau tertulis. Hal ini dapat dimaklumi mengingat pada umumnya pesantren lebih mementingkan proses belajar mengajar. Selain itu, faktor lainnya adalah para pengurus dan pengajar juga tidak semuanya berasal dari lulusan pendidikan S1.

\section{b. Pelaksanaan Pembelajaran.}

Setelah melakukan perencanaan pembelajaran, langkah berikutnya adalah merealisasikan semua yang telah dirancang ke dalam proses belajar mengajar. Pelaksanaan pembelajaran merupakan kegiatan menyeluruh yang mencerminkan interaksi antara input dinamis dan input statis yang dikendalikan oleh input manajemen. Input dinamis terdiri dari pimpinan lembaga, para pendidikan, tenaga kependidikan, peserta didik, dan orang tua peserta didik. Input statis meliputi lingkungan pembelajaran dan sarana prasarana belajar, sedangkan input manajemen merupakan seperangkat aturan yang mengendalikan interaksi input dinamis dan input statis dalam suatu proses, visi dan misi, uraian tugas pendidik dan tenaga kependidikan, dan tata tertib. (Alben Ambarita, $2006: 75$ )

Pelaksanaan pembelajaran adalah suatu kegiatan yang bernilai edukatif mewarnai interaksi yang terjadi antara guru dan siswa. Interaksi yang bernilai edukatif dikarenakan pelaksanaan pembelajaran yang dilakukan diarahkan untuk mencapai tujuan tertentu yang telah dirumuskan sebelum pelaksanaan pembelajaran dimulai. (Syaiful Bahri, $2010: 1$ )

Pelaksanaan Pembelajaran Bahasa Arab di Pondok Pesantren Riyadhul Ulum Wa Da'wah dan Pondok Pesantren Darussalam Kab. Tasikmalaya tidak hanya dilakukan melalui proses pembelajaran yang bersifat klasikal saja. Selain pembelajaran berbasis klasikal pembelajaran Bahasa Arab melalui :

1) Pemberian Kosa Kata (liko'il mutarodifat)

Pemberian kosa kata tersebut di berikan oleh pegurus kamar atau LMTV (language motivator) setiap harinya di saat pagi pada saat sesudah santri keluar dari mesjid dan setiap harinya diberikan kosa kata baru untuk santri mangetahui 
setiap kosa kata yang di berikan, dan diberikan setiap harinya dua kosa kata dan tiap kosa kata akan diberikan oleh pengurus contoh dari kosa kata tersebut. Dan santri berikan tugas dari kosa kata tersebut untuk membuat contoh kalimat agar santri tahu bagaimana menggunakan kasa kata tersebut. Serta dihafalakan dan digunakan dalam percakapan sehari-hari. Dan pada esok harinya pengurus akan memeriksa tugas santri tersebut. Dan pada hari Jumat akan diadakan evaluasi mingguan santri dari kosa kata- kosa kata tersebut.

\section{2) Latihan Pidato(muhadoroh)}

Latihan pidato tersebut dibimbing oleh pengurus santri (bagian bahasa) dan di pandu oleh kakak kelas dan diadakan setiap minggu satu kali. Setelah santri keluar dari pembelajaran klasikal dapat dilatih untuk berbicara bahasa arab sesuai dengan konsep yang dia buat sendiri, akan tapi sebelumnya konsep tersebut sudah di koreksi oleh pembimbing masing-masing.

3) Percakapan (muhadasah)

Percakapan tersebut dibimbing oleh pengurus santri (bagian bahasa) kegiatan tersebut diadakan pada hari hari jum'at. Pelaksanaan muhadatsah tersebut diberikan oleh bagian bahasa, cara pemberiannya secara serentak bagian bahasa membacanya serta menjelaskan kaidah-kaidah yang ada dalam percakapan tersebut. Santri hurus sudah hafal semua dan bagi santri yang belum hafal akan diberi sangsi dari penegak bahasa.

4) Kaidah berbahasa (qowaid)

Kaidah berbahasa ini dibebankan kepada para ustadz, yang di berikan pada saat pelajaran diniyah. Pelajaran kaidah tersebut meliputi nahwu dan sorof. Agar santri mampu memahami betuk-betuk kata serta tau perubahannya

5) Drama Kontes

Pelaksanaan drama kontes ini adalah bagian dari praktik kebahasaan yang dilakukan setelah selesai ujia tulis baik tengah semester ataupun akhir semester. Hal ini dilakukan sebagai salah satu bentuk implementasi praktik berbahasa dalam internalisasi kebahasaan dalam kehidupan sehari-hari.

\section{c. Evaluasi Pembelajaran}

Evaluasi pembelajaran dilakukan untuk mengetahui apakah perencanaan pembelajaran yang telah dirumuskan dan direalisasikan dalam pelaksanaan 
pembelajaran telah tercapai atau belum. Pada UU No. 20/ 2003 tentang Sistem Pendidikan Nasional Pasal 58 ayat 1 berbunyi "evaluasi hasil belajar peserta didik dilakukan oleh pendidik untuk memantau proses, kemajuan, dan perbaikan hasil belajar peserta didik secara berkesinambungan".

Evaluasi proses pengajaran adalah suatu rangkaian kegiatan yang dilakukan dengan sengaja untuk melihat atau mengetahui seberapa tinggi tingkat keberhasilan dari kegiatan yang direncanakan. (Suharsimi Arikunto, 2006 : 290)

Evaluasi pembelajaran mempunyai bentuk yang beragam ditinjau dari sasaran yang akan dicapai. Menurut Mohamad Ali (1985: 127) mengungkapkan bentuk evaluasi pembelajaran dapat dibedakan menjadi empat macam yaitu:

1) Evaluasi formatif yaitu evaluasi yang dilaksanakan setiap kali selesai pelaksanaan pengajaran tertentu. Manfaat yang dicapai adalah untuk menilai keberhasilan proses belajar mengajar untuk suatu pelajaran tertentu.

2) Evaluasi sumatif yaitu dilaksanakan setiap akhir pengajaran suatu program atau beberapa unit pelajaran tertentu. Sasaran yang dicapai untuk menilai keberhasilan proses belajar atau kurikulum berdasarkan pengalaman belajar yang diperoleh siswa.

3) Evaluasi diagnostik yaitu dilaksanakan untuk meneliti atau mencari sebab kegagalan peserta didik dalam mempelajari mata pelajaran.

4) Evaluasi penempatan dilakukan jika kurikulum menuntut adanya pembedaan peserta didik berdasarkan kelompok, baik keberhasilan atau program yang dipilih.

Pada praktiknya Pesantren Riyadhul Ulum Wa Da'wah dan Pesantren Darussalam Kab. Tasikmalya sudah menerapkan evaluasi sumatif dan formatif, Evaluasi formatif dilakukan setelah pokok bahasan selesai dipraktikkan dalam mengevaluasi latihan ceramah, khutbah, tahsin, dan muroja'ah, sedangkan evaluasi sumatif dilakukan setiap akhir semester dengan memberikan tes soal dan pertanyaan yang diberikan.

\section{Pembelajaran Bahasa Arab}

Bahasa merupakan penghubung antara manusia dengan manusia, 
manusia dengan masyarakat dan masyarakat dengan masyarakat lainnya. Dapat dikatakan bahwa bahasa arab adalah bahasa yang digunakan oleh orang-orang arab untuk mengutarakan maksud dan tujuan mereka secara lisan, bahasa arab juga berasal dari suku Quraisy di daerah arab dan kemudian menyebar diseluruh penjuru dunia bersama dengan meluasnya agama Islam dan AI-Qur'an. Bahasa arab sendiri memiliki 4 maharoh yang harus dimiliki oleh sipembicara agar bisa sempurna, yaitu: Maharotul Istima' (keterampilan mendengar) dan Maharotul Kalam (ketrampilan berbicara), Maharotul Qiro'ah (ketrampilan membaca) dan Maharotul Kitabah (ketrampilan menulis). (Nurul Salis dkk, 2016 : Jurnal At-Ta'dib Vol. 11, No. 2)

\section{a. Keterampilan Mendengar (Mahârah al-Istimâ')}

Keterampilan mendengar (Mahârah al-Istimâ') merupakan keterampilan awal dalam pembelajaran bahasa, baik bahasa ibu maupun bahasa asing termasuk didalamnya adalah Bahasa Arab. Dengan demikian kegagalan dalam pembelajaran keterampilan ini dapat mengakibatkan kegagalan pada pembelajaran keterampilan- keterampilan bahasa berikutnya. (Mohammad Thoha, 2012 : Jurnal OKARA, Vol. I, Tahun 7)

Dalam pembelajaran istima' metode yang paling tepat digunakan adalah metode langsung (al- tharîqah al-mubâsyarah atau direct method). Dalam metode ini pengajar mengantarkan seluruh materi pelajaran dengan bahasa Arab, dan sangat tidak dibenarkan menggunakan bahasa ibu. Apabila dalam instruksi pembelajaran, peserta didik tidak dapat menjangkau atau tidak dapat memahaminya, maka pengajar berusaha untuk menjelaskan dengan bahasa yang lebih sederhana dengan tetap menggunakan Bahasa Arab. Penggunaaan alat peraga (wasîlah al-îdlâh) sangat dianjurkan untuk mempercepat pemahaman peserta didik. Dengan kedisiplinan yang tinggi, peserta didik akan berusaha untuk memahami materi pelajaran secara berkala.

Pemilihan materi atau topik pelajaran yang sesuai dengan minat dan kesenangan siswa. Siswa akan termotivasi belajar apabila ia menyenangi materi pelajaran. Kaidah ini berlaku dalam pelajaran keterampilan mendengar (mahârah al- istimâ'). Oleh karena itu, pengajar harus pandai memilih topik yang disenangi peserta didik. Topik yang disenangi tersebut biasanya berupa topik- 
topik yang telah dialami atau dikenal peserta didik dalam kehidupannya. Hal yang perlu diperhatikan oleh pendidik dalam memilih topik pelajaran adalah penyusunan topik-topik pelajaran yang harus dimulai dari topik yang paling mudah dan sederhana serta akrab dengan dunia siswa, kemudian meningkat sedikit demi sedikit menuju topik-topik yang sulit.

\section{b. Keterampilan Berbicara (Mahârah al-Kalâm)}

Keterampilan berbicara (mahârah al-kalâm) adalah kelanjutan dari keterampilan mendengar. Kedua keterampilan ini saling terkait. Orang yang pendengarannya baik dimungkinkan untuk dapat berbicara dengan baik pula, sebaliknya orang yang tidak dapat mendengar dengan baik tidak akan dapat berbicara dengan baik. Oleh karena itu pengajar bahasa bisa melaksanakan pembelajaran keterampilan berbicara seraya mengiringi keterampilan mendengar yang telah dimiliki peserta didik. Pemahaman peserta didik tentang topik bahasan yang diperolehnya melalui proses mendengar dapat dimanfaatkan sebagai langkah awal pengajaran berbicara. Pada dasarnya keterampilan berbicara merupakan pengungkapan (ta'bir) dari isi pemikiran yang telah terekam di dalam pemahaman peserta didik. (Suharmon, 2009 : Ta'dib Vol. 12, No 1)

Oleh karena hubungannya yang sangat dekat dengan pembelajaran keterampilan mendengar, maka dalam melaksanakan pembelajaran keterampilan berbicara (Mahârah al-Kalâm) seorang pengajar bahasa Arab dapat memilih topik- topik yang sederhana dan dekat dengan dunia siswa sebelum topik tersebut meningkat sesuai dengan tingkat kesulitannya.

Dalam kaitannya dengan manajemen, pembelajaran bahasa Arab, seorang pengajar dapat memperhatikan tingkat penguasaan peserta didik tentang Bahasa Arab yang didukung oleh kegiatan mereka di luar sekolah seperti dalam lingkungan keluarga, lingkungan tempat tinggal, dan lingkungan bermain. Tidak jarang ditemukan peserta didik yang telah menempuh pendidikan formal seperti sekolah dan madrasah juga mengikuti program pendidikan lainnya seperti pondok pesantren dan sebagainya. Dengan demikian kegiatan mereka di lembaga pendidikan non formal tersebut dapat dijadikan pertimbangan bagi pengajar bahasa untuk menentukan topik dan metode pembelajaran yang sesuai dengan kemampuan bahasa serta minat dan bakat mereka. 


\section{c. Keterampilan Membaca (Mahârah al-Qirâah)}

Untuk memiliki keterampilan membaca (Mahârah al-Qirâah) yang baik dibutuhkan kecermatan tersendiri. Hal ini dikarenakan membaca merupakan kegiatan memahami isi pemikiran penulis yang tentu saja tidak sedang berada dihadapan pembaca. Kegiatan menarik pemahaman tersebut lebih sulit dibandingkan dengan pengambilan pemahaman melalui proses pembicaraan atau dialog yang melibatkan langsung antara pembicara (mutakallim) dan pendengar (sâmi'), di mana proses dialog tersebut dapat melibatkan bahasa tubuh yang dapat membantu terjadinya kesepahaman yang baik antara kedua belah pihak.

Dengan memperhatikan tingkat kesulitan yang ada pada kegiatan membaca, maka dalam pelaksanaan pembelajaran dengan materi keterampilan membaca (Mahârah al-Qirâah), seorang pengajar dapat juga menggunakan pendekatan pemilihan materi bacaan (al- Mâddah al-Maqrûah) secara berjenjang dari materi yang mudah menuju materi yang semakin sulit, dari materi yang sangat dekat dengan dunia siswa menuju materi yang semakin abstrak bagi pemahaman mereka. (Jabal Nur, 2015 : Jurnal Al-Ta'dib, Vol. 8 No. 1)

Dalam kaitannya dengan manajemen pembelajaran, pengajaran keterampilan membaca (Mahârah al-Qirâah) di lingkungan pendidikan agama dapat dilaksanakan dengan menarik korelasi pelajaran bahasa Arab dengan pelajaran lainnya. Sebagaimana dimaklumi bahwa kurikulum pendidikan di lingkungan pendidikan agama memiliki kelebihan tersendiri dibandingkan dengan kurikulum pendidikan umum. Kelebihan tersebut dapat dicontohkan dalam komposisinya yang sebagian besar terdiri dari materi-materi agama Islam yang sebagian besar pula referensi dan acuannya ditulis dengan bahasa Arab. Keadaan seperti ini dapat dijadikan peluang oleh pengajar untuk menarik korelasi antara pelajaran bahasa Arab dengan pelajaran agama lainnya. Korelasi tersebut bisa berupa penyediaan bahan bacaan untuk melatih keterampilan membaca (Mahârah al-Qirâah) sekaligus sebagai media pendalaman materi pelajaran yang lain. Langkah seperti ini akan melahirkan beberapa keuntungan bagi peserta didik, tenaga pengajar dan lembaga itu sendiri. Keuntungan tersebut antara lain pendidik adalah efisiensi materi, 
kesinambungan materi-materi pelajaran dan timbulnya minat belajar siswa yang tinggi yang disebabkan siswa merasa senang dengan apa yang mereka pelajari. (Mohammad Thoha, 2012 : Vol. I, Tahun 7, Mei 2012).

\section{d. Mengajar Keterampilan Menulis (Mahârah al-Kitâbah)}

Keterampilan menulis (Mahârah al-Kitâbah) merupakan keterampilan terakhir dalam beberapa keterampilan bahasa. Untuk menguasai keterampilan ini secara baik dibutuhkan penguasaan keterampilan bahasa sebelumnya dengan baik pula. Hal ini dikarenakan menulis merupakan kegiatan menuangkan isi pikiran dalam bentuk tulisan yang tujuannya untuk dapat dipahami oleh pembaca yang tentu saja tidak sedang berhadapan atau bahkan tidak satu masa dengan penulis. Seluruh aspek bahasa yang meliputi penguasaan struktur (qawâ'id), kosa kata (mufradât), sastra (balâghah), dan pilihan diksi yang baik (ikhtiyâr al- kalimah) sangat dibutuhkan dalam kegiatan menulis. (Mohammad Thoha, 2012 : Vol. I, Tahun 7, Mei 2012)

Problematika pembelajaran bahasa Arab sebenarnya cukup kompleks, mulai dari problematika linguistik sampai non linguistik. Problematika linguistik yaitu problematika phonetik/tata bunyi, kosa kata, tulisan, morfologi, sintaksis, dan semantik. Sedangkan problematika non linguistik adalah problematika yang muncul diluar zat bahasa itu sendiri, hal ini dapat dilihat dari beberapa unsur, diantaranya: (1) guru/pendidik yang kurang memiliki kompetensi sebagai pengajar Bahasa Arab, baik kompetensi paedagogik, profesional, personal atau Sosial. (2). Peserta didik yang tidak mempunyai motivasi kuat dalam pembelajaran bahasa Arab, atau latar belakang peserta didik dalam pemahaman bahasa Arab. (3). Materi ajar yang kurang relevan lagi dengan kebutuhan yang ada bagi peserta didik. (4). Sarana dan prasarana yang kurang memadai dan mendukung dalam proses pembelajaran bahasa Arab. (Nandang Syarif Hidayat, 2012 : Jurnal Pemikiran Islam 37, no. 1, 82-92.)

Fakta di lapangan memang masih banyak ditemukan guru yang missmatch, artinya tidak sesuai antara bidang ilmu yang dipelajari (latar belakang pendidikan) dengan mata pelajaran yang diampu. Banyak guru bahasa Arab yang tidak berlatar belakang sarjana atau magister Pendidikan Bahasa Arab atau Sastra Arab. Pada sisi lain kurang adanya kebijakan atau ketentuan yang mengikat 
dari lembaga yang memungkinkan penciptaan bi'ah lughawiyah. Akibatnya mayoritas pembelajaran bahasa Arab lebih berorientasi pada kemampuan bahasa secara pasif dan sebatas ilmu bahasa Arab yang mengutamakan pemahaman qawaid dan membaca.

"Pondok Pesantren Modern Gontor Ponorogo, membutuhkan waktu bertahun-tahun untuk tetap konsisten dengan metode pembelajarannya. Gontor mampu membangun dan memelihara atau mengorganisasikan lingkungan di lembaganya untuk menciptakan kondisi belajar dalam hal ini adalah bi ah 'arabiah yang baik, yaitu lingkungan yang semua kegiatan diwarnai dan diaktualisasikan dengan bahasa Arab. Sehingga metode langsung (thariqah mubasyarah/direct method), dalam pembelajaran bahasa Arab berhasil dilakukan. Sampai saat ini Gontor mampu berperan banyak dalam upaya pencapaian keberhasilan sebuah pembelajaran bahasa Arab di tanah air". (Wisnawati Loeis, 2011 : Turats 7, no. 2 62-70).

Keberadaan Pondok pesantren adalah salah satu sarana penunjang dalam proses pembelajaran berbahasa atau lebih sederhananya pondok merupakan laboratorium bahasa. Proses pembiasaaan pada sebuah lingkungan belajar menjadi salah kunci keberhasilan pembelajaran bahasa Arab yang menekankan pada pembinaan keterampilan berkomunikasi baik lisan maupun tulisan.

Pembelajaran bahasa memiliki banyak pendekatan, strategi, dan metode. Imam Makruf menyebutkan ada dua pendekatan atau teori pokok dalam pembelajaran bahasa Arab, yaitu nadzariyatul wihdah (teori kesatuan) dan nadzariyatul furu' (teori cabang). Dalam teori cabang, bahasa Arab dipelajari secara terpisah pisah. Artinya, bahasa Arab diajarkan dengan berbagai cabangnya yang berdiri sendiri-sendiri, seprti qira'ah, ta'bir, imla' qawa'id, balaghah, khat, dan sebagainya. (Imam Makruf, 20, Cendekia Vol. 14 No. 2,)

Proses pembelajaran bahasa Arab yang dilaksanakan di Pesantren Riyadhul Ulum Wa Da'wah dan Pesantren Darussalam Kab. Tasikmalaya menerapkan model integrasi. Dimaknai mengintegrasikan antara semua maharah lughawiyah dalam pembelajaran, yaitu maharah istima', kalam, qira'ah, dan kitabah menjadi satu kesatuan dalam proses pembelajaran. Model 
integrasi lainnya juga dapat dilakukan dengan mengaitkan pembelajaran bahasa Arab dengan pembelajaran lainnya yang berbasis keagamaan. Hal ini berarti bahwa untuk membina keterampilan bahasa Arab tidak hanya dilakukan pada materi pelajaran bahasa Arab semata, tetapi juga dilakukan pada mata pelajaran lainnya.

\section{SIMPULAN}

Manajemen pembelajaran bahasa Arab adalah proses perencanaan, pelaksanaan serta pengawasan/evaluasi, usaha-usaha para manajer dan penggunaan sumber daya lainnya agar pembelajaran bahasa Arab mencapai tujuan secara efektif. Pelaksanaan pembelajaran bahasa Arab di Pesantren Riyadhul Ulum Wa Da'wah dan Pesantren Darussalam Kab. Tasikmalya menekankan pada ustadz dalam penyusunan silabus dan penyusunan rencana pelaksanaan pembelajaran dalam hal ini menggunaka l'dadu At Tadris dan penyampaian pembelajaran di kelas dengan memanfaatkan berbagai sumber belajar. Evaluasi pembelajaran dilakukan melalui kegiatan evaluasi formatif, evaluasi sumatif dan evaluasi diagnostik.

Keberhasilan yang dicapai dalam pembelajaran bahasa Arab dikatakan berhasil, hal ini dapat dilihat dari tujuan pembelajarannya yaitu para santri dapat berbicara dalam proses kehidupan kesehariannya di pondok Pesantren. Tujuan keduanya yaitu santri dapat menulis hal ini dapat diukur melalui proses penyiapan teks pidato yang dipersiapkan untuk kegiatan muhadloroh.

\section{DAFTAR PUSTAKA}

Al-Amin, Nurul Salis dan Syaputra, Erwin, Kemampuan Pengurus Rayon dalam Ta’bir Tahriri di Pondok Modern Darussalam Gontor, Jurnal At Ta'dib, Vol. 11, No. 2, Desember 2016

Ambarita, Alben. (2006). Manajemen Pembelajaran. Jakarta: Departemen Pendidikan Nasional.

Arikunto, Suharsimi. (2006). Prosedur Penelitian Suatu Pendekatan Sistem. Jakarta: PT Rineka Cipta. 
Bahri, Syaiful \& Zain, Azwan. (2010). Setrategi Belajar Mengajar. Jakarta: Rineka Cipta.

Dahlan, Juwairiyah, (1992) Metode Belajar Mengajar Bahasa Arab Surabaya: al-Ikhlas.

Danarwati, Yanti Sri, SS., SE., MM. Manajemen Pembelajaran Dalam Upaya Meningkatkan Mutu Pendidikan, Jurnal Pendidikan.

Fatimah Kadir , St., Keterampilan Mengelola Kelas Dan Implementasinya Dalam Proses Pembelajaran, Jurnal Al-Ta'dib, Vol. 7 No. 2 JuliDesember 2014

Hidayat, Nandang Syarif, "Problematika Pembelajaran Bahsa Arab," Jurnal Pemikiran Islam 37, no. 1 (June 2012): 82-92.

Loeis, Wisnawati, "Metode Langsung Dalam Pembelajaran Bahasa Arab," Turats 7, no. 2 (Agustus 2011): 62-70.

Majid, Abdul. (2009). Perencanaan Pembelajaran Mengembangkan Standar Kompetensi Guru. Bandung: Remaja Rosdakarya Offset.

Makruf, Imam, Manajemen Integrasi Pembelajaran Bahasa Arab di Madrasah, Cendekia Vol. 14 No. 2, Juli - Desember 180

Mulyasa. (2006). Kurikulum Tingkat Satuan Pendidikan. Bandung: PT Remaja Rosdakarya. hlm.243

Nur, Jabal, Konsep Nadzariyyah Alwihdah Dalam Pembelajaran Bahasa Arab, Jurnal Al-Ta'dib, Vol. 8 No. 1, Januari-Juni 2015

Rayuni, Dewi, Manajemen Pembelajaran Di Madrasah Aliyah Negeri (Man) 3 Palembang, Jurnal TA’DIB, Vol. XV No. 01. Edisi, Juni 2010

Shaleh, Abdul Rahman. 2004. Madrasah dan Pendidikan Anak Bangsa: Visi, Misi dan Aksi. Rajawali Press, Jakarta.

Suharmon, Upaya Peningkatan Keterampilan Berbicara Siswa Pada Mata Pelajaran Bahasa Arab Melalui Latihan Komunikatif Di Mtsn Paninjauan Kabupaten Tanah Datar Ta'dib Vol. 12, No. 1 (Juni 2009)

Tilaar, H.A.R., (1994) Manajemen Pendidikan Nasional, Kajian Pendidikan Masa Depan (Bandung; Remaja Rosdakarya, hlm.

Thoha, Mohammad, Pembelajaran Bahasa Arab Dengan Pendekatan Manajemen Berbasis Sekolah, Jurnal OKARA, Vol. I, Tahun 7, Mei 2012 